\title{
Phonological Substitution is Motivated by Adjacent Phonological Features: Evidence from Classical Arabic
}

\author{
Zainab Sa’aida \\ Correspondence: Zainab Sa'aida, Department of English, Tafila Technical University, Tafila 66110, Jordan \\ ORCID: https://orcid.org/0000-0001-6645-6957,E-mail: z.saaida@ttu.edu.jo
}

Received: Sep. 20, 2020

Accepted: Oct. 25, $2020 \quad$ Online Published: Nov. 13, 2020

doi:10.5430/elr.v9n4p23

URL: https://doi.org/10.5430/elr.v9n4p23

\begin{abstract}
This article aims at investigating phonological substitution in classical Arabic. I hypothesise that consonantal and vocalic substitution is motivated by phonological features of adjacent consonantal or vocalic segments. Data of the study were collected from classical Arabic literary works in Aldiwan - encyclopaedia of Arabic poetry. Data were analysed in the framework of Chomsky and Halle's SPE theory. Findings of the study have revealed that phonological features of consonantal or vocalic segments motivate other adjacent consonants to undergo a phonological substitution process in specific phonological contexts in classical Arabic. It has been revealed that the glide $/ \mathrm{w} /$ surfaces as $/ \mathrm{t} /$ when it is followed by $/ \mathrm{t} /$ or as $/ \mathrm{j} /$ when it occurs between two vowels, the first of which is high short /i/ and the second is low long /a:/, word-internally. The phoneme /t/ becomes /ț/ when it is preceded by /ș/, $/ \mathrm{d} /$, /ț/ or /ộ/ across a syllable, and it surfaces as /d/ when it is preceded by /d/, /z/ or /ठ/ word-internally. It has been also found that the long vowels /a:, i:, u:/ replace glide phonemes in vocalic substitution processes when glides are adjacent to corresponding short vowels either word-internally or word-finally.
\end{abstract}

Keywords: consonantal substitution, vocalic substitution, phonological features, SPE theory, classical Arabic

\section{Introduction}

When one speech sound, which is either a consonantal or vocalic segment, replaces another consonantal or vocalic segment in a natural language, the phenomenon is called phonological substitution. The term 'phonological substitution' is used to indicate that a set of universal phonological features tend to replace another different set of universal phonological features in a specific phonological context in a language. This article aims at investigating phonological substitution of classical Arabic (CA, henceforth) segments in specific phonological contexts. I hypothesise that consonantal and vocalic substitution is motivated by phonological features of adjacent consonantal or vocalic segments in CA. Data of the study will be collected from classical Arabic literary works in Aldiwan encyclopaedia of Arabic poetry, (2013). Data will be analysed in the framework of Chomsky and Halle's (1968) SPE (Sound Pattern of English) theory. I opted for this theory as it deals with a universal set of phonological features that can be used to define classes of speech sounds in any natural language. It also enables phonologists to formulate an infinite number of phonological rules by using a set of phonological features without the necessity of listing all segments in phonological rules. In section 2, I summarise the main view and aspects of Chomsky and Halle's (1968) SPE theory, and I apply the theoretical concepts to CA phonemic inventory (see appendix 1 for phonetic description of CA consonantal and vocalic phonemes). A phonological analysis of consonantal and vocalic substitution in CA is provided in section 3. I conclude in section 4.

\section{Chomsky and Halle's SPE Theory}

The theory of distinctive features in Jakobson, Fant, and Halle (1951) was adopted by Chomsky and Halle (1968) with minor changes in their SPE model. The view of the SPE theory is that a segment comprises a matrix of unordered phonological distinctive features and an utterance consists of sequential columns of segments, in which each column corresponds to a single segment. Chomsky and Halle (1968) proposed changes for the features that their universal feature set comprises. The SPE theory comprises the major class features of [syllabic], [consonantal], and [sonorant], as shown in table (1). 
(1) Major class features of CA consonants

\begin{tabular}{|c|c|c|c|c|c|c|c|c|c|c|c|c|c|c|c|c|c|c|c|c|c|c|c|c|c|c|c|c|}
\hline & $\mathrm{t}$ & $\mathrm{t}$ & $\mathrm{k}$ & $\mathrm{q}$ & $?$ & $\mathrm{~b}$ & d & d & $\mathrm{f}$ & $\theta$ & ð & S & Ṣ & $\int$ & $\chi$ & h & $\mathrm{h}$ & $\mathrm{Z}$ & ð̣ & ds & B & $\mathrm{S}$ & $\mathrm{m}$ & $\mathrm{n}$ & 1 & $\mathrm{r}$ & $\mathrm{j}$ & W \\
\hline syllabic & - & - & - & - & - & - & - & - & - & - & - & - & - & - & - & - & - & - & - & - & - & - & - & - & - & - & - & - \\
\hline sonorant & - & - & - & - & - & - & - & - & - & - & - & - & - & - & - & - & - & - & - & - & - & - & + & + & + & + & + & + \\
\hline consonantal & + & + & + & + & + & + & + & + & + & + & + & + & + & + & + & + & + & + & + & + & + & + & + & + & + & + & - & - \\
\hline
\end{tabular}

The feature [retracted tongue root] has been adopted from Rose (1996) to refer to classical Arabic consonants /ț/, /q/,

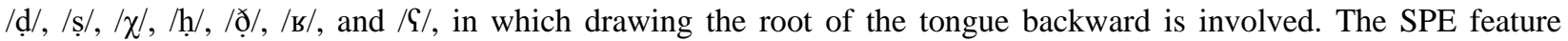
system also comprises a set of universal stricture features of [continuant], [strident], [nasal], and [lateral], see table (2).

(2) Stricture features of CA consonants

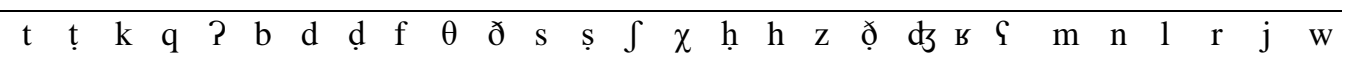

\begin{tabular}{|c|c|c|c|c|c|c|c|c|c|c|c|c|c|c|c|c|c|c|c|c|c|c|c|c|c|c|c|c|}
\hline continuant & - & - & - & - & - & - & - & - & + & + & + & + & + & + & + & + & + & + & + & + & + & + & - & - & + & + & + & + \\
\hline strident & - & - & - & - & - & - & - & - & - & - & - & + & + & + & - & - & - & + & - & - & - & - & - & - & - & - & - & - \\
\hline nasal & - & - & - & - & - & - & - & - & - & - & - & - & - & - & - & - & - & - & - & - & - & - & + & + & - & - & - & - \\
\hline lateral & - & - & - & - & - & - & - & - & - & - & - & - & - & - & - & - & - & - & - & - & - & - & - & - & + & - & - & - \\
\hline
\end{tabular}

The SPE system of laryngeal features consists of [voice] and [glottal closure] as shown in table (3).

(3) Laryngeal features of CA consonants

$\begin{array}{llllllllllllllllllllllllllll}\mathrm{t} & \mathrm{t} & \mathrm{k} & \mathrm{q} & \mathrm{P} & \mathrm{b} & \mathrm{d} & \mathrm{d} & \mathrm{f} & \theta & \partial & \mathrm{s} & \mathrm{s} & \int & \chi & \mathrm{h} & \mathrm{h} & \mathrm{z} & \partial & \mathrm{d} & \text { в } & \mathrm{G} & \mathrm{m} & \mathrm{n} & \mathrm{l} & \mathrm{r} & \mathrm{j} & \mathrm{w}\end{array}$

\begin{tabular}{llllllllllllllllllllllllllllllllll}
\hline voice & - & - & - & - & - & + & + & + & - & - & + & - & - & - & - & - & - & + & + & + & + & + & + & + & + & + & + & + \\
\hline $\begin{array}{l}\text { glottal } \\
\text { closure }\end{array}$ & - & - & - & - & + & - & - & - & - & - & - & - & - & - & - & - & - & - & - & - & - & + & - & - & - & - & - & - \\
\hline
\end{tabular}

Chomsky and Halle (1968) proposed the features [anterior] and [coronal] for consonant place as shown in (4).

(4) Place features of CA consonants

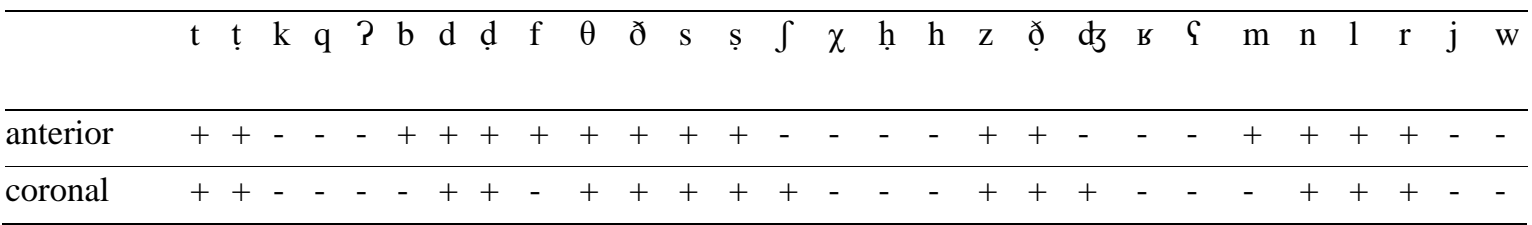

They also proposed the features [high], [low], [back], [round], and [tense] for vowel place, see table (5). The feature [round] is used for rounding in vowels and for labialization in consonants. 
(5) Place features of CA vowels

\begin{tabular}{lcccccc}
\hline & $\mathrm{i}:$ & $\mathrm{u}$ & $\mathrm{a}$ & $\mathrm{i}$ & $\mathrm{u}$ & $\mathrm{a}$ \\
\hline high & + & + & - & + & + & - \\
\hline low & - & - & + & - & - & - \\
\hline back & - & + & - & - & + \\
\hline round & - & + & - & - & - & - \\
\hline tense & + & + & + & - & +
\end{tabular}

In the following section, I will analyse phonological substitution in CA.

\section{Phonological Substitution in CA}

This section comprises two sub-sections: consonantal substitution and vocalic substitution in CA.

\subsection{Consonantal Substitution in CA}

In consonantal substitution, a consonant replaces a vowel or a consonant. Consider the list in (6) where a consonant is substituted for another consonant.

(6)

\begin{tabular}{|c|c|c|c|}
\hline Root & Input & Output & Gloss \\
\hline wașaf & /Riwtașaf/ & [?ittașaf] & 'described \\
\hline wasaq & /Piwtasaq/ & [?ittasaq] & 'organised \\
\hline waka? & /Riwtaka?/ & [?ittaka?] & 'leant' \\
\hline wadzah & /Piwtadzah/ & [Pittadzah] & 'headed' \\
\hline wafaq & /Piwtafaq/ & [Pittafaq] & 'agreed' \\
\hline waḍah & /Piwtaḍaḩ/ & [?ittaḍah] & 'clarified' \\
\hline
\end{tabular}

Tri-consonantal root morphemes in the list in (6) begin with the round sonorant /w/. The phoneme /w/ is replaced by $/ t /$ in the templatic pattern for form VIII verb, CVC.CV.CVC, as shown in (7).

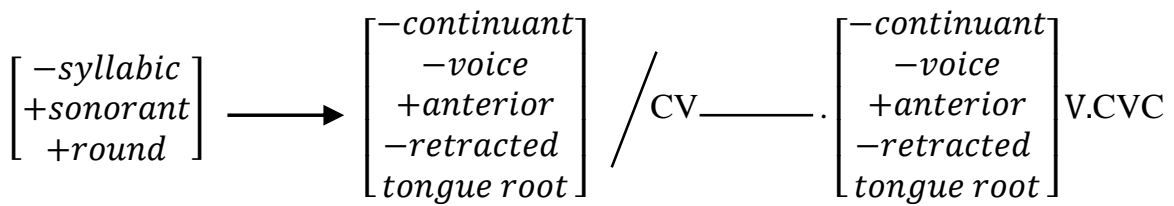

The rule in (7) changes the phoneme /w/ into /t/ in the phonological context when /w/, the second consonant in CVC.CV.CVC, is followed by /t/ across a syllable in the templatic pattern CVC.CV.CVC. Now let us consider the list in (8) where tri-consonantal root morphemes begin with /ș/, /ḍ/, /ț/, or /ọ/.

\begin{tabular}{|c|c|c|c|}
\hline Root & Input & Output & Gloss \\
\hline salah & /Piștalaḥ/ & [Pișțalaḥ] & 'reconciled' \\
\hline darab & /Piḍtarab/ & [?iḍțarab] & 'confused' \\
\hline 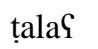 & /PițtalaS/ & [PitțalaS] & 'appeared' \\
\hline & /PistanaG/ & [PistanaY] & 'produced' \\
\hline
\end{tabular}

The following phonological representation presents the phonological substitution that words in (8) have undergone. 
(9) $\left[\begin{array}{c}\text {-continuant } \\ \text {-voice } \\ \text { +anterior } \\ \text {-retracted } \\ \text { tongue root }\end{array}\right] \longrightarrow\left[\begin{array}{c}\text { - continuant } \\ \text {-voice } \\ \text { +anterior } \\ \text { +retracted } \\ \text { tongue root }\end{array}\right] / \mathrm{CV}\left[\begin{array}{c}+ \text { anterior } \\ + \text { coronal } \\ + \text { retracted } \\ \text { tongue root }\end{array}\right] \cdot-\mathrm{V} . \mathrm{CVC}$

The rule in (9) captures the process found in CA by which a /t/, the third consonant in the templatic pattern for form VIII verb, CVC.CV.CVC), becomes /ț/ when it is preceded by /ṣ/, / ̣̦/, /ț/ or /ọ/ across a syllable in the templatic pattern CVC.CV.CVC, e.g. in words like /Piștalaḥ/ 'reconciled' and /Piḍtarab/ 'confused' which surface as [?ișțalaḥ] and [?id̦țarab], respectively. The following list shows a different set of words in which the phoneme /t/ undergoes a different phonological substitution.

\begin{tabular}{|c|c|c|c|}
\hline Root & Input & Output & Gloss \\
\hline zadzar & /P1ztadzar/ & [?1zdadzar] & 'rebuked' \\
\hline da $\theta$ ar & /PıdtaOar/ & [Pıdda $\theta a r]$ & 'covered up' \\
\hline daxar & 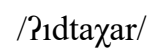 & [?1dda $\chi a r]$ & 'saved' \\
\hline ðakar & /P1ðtakar/ & [?ıðdakar] [?1ddakar] & 'remembered' \\
\hline
\end{tabular}

The phoneme /t/ can also be replaced by /d/ in a different phonological context in the same templatic pattern, as shown in (11).

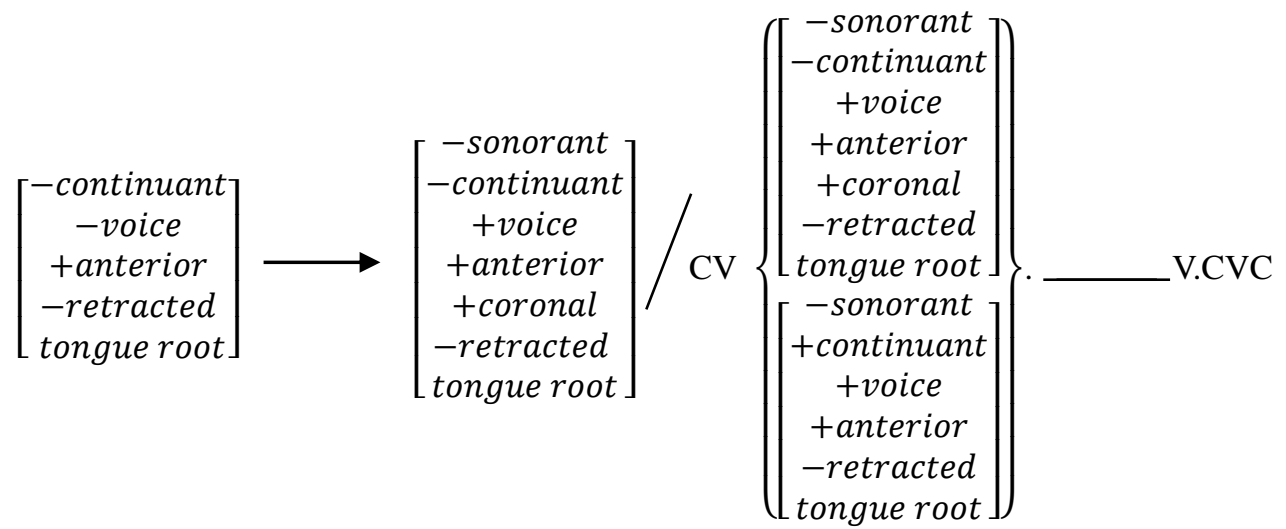

The rule in (11) shows that the phoneme /t/ surfaces as /d/ when it is preceded by /d/, /z/ or / $/$ across a syllable in the templatic pattern for form VIII verb, CVC.CV.CVC. This rule captures the fact that $/ \mathrm{t} / \mathrm{undergoes}$ the same consonantal substitution process, despite the difference in environment. The segments $/ \mathrm{d}, \mathrm{z}, \mathrm{\partial} /$ cannot constitute a natural class because /d/ is [-continuant] while /z/ and /ð/ are [+continuant]. Now let us consider the list in (12) where $/ \mathrm{w} /$ is preceded by a high short vowel and is followed by a low long vowel word-internally.

$\begin{array}{llll}\text { Root } & \text { Input } & \text { Output } & \text { Gloss } \\ \text { șawam } & \text { /șiwa:m/ } & \text { [șija:m] } & \text { 'fasting' } \\ \text { diwar } & \text { /diwa:r/ } & \text { [dija:r] } & \text { 'houses' }\end{array}$

The consonantal substitution process that occurs in the words /șiwa:m/ 'fasting' and /diwa:r/ 'houses' is represented phonologically in (13).

$$
\left[\begin{array}{c}
\text {-syllabic } \\
\text { +sonorant } \\
\text { +round }
\end{array}\right] \longrightarrow\left[\begin{array}{c}
\text {-syllabic } \\
+ \text { sonorant } \\
\text { consonantal } \\
\text {-round }
\end{array}\right] / \mathrm{C}\left[\begin{array}{c}
\text { syllabic } \\
+ \text { high } \\
\text {-back } \\
\text {-tense }
\end{array}\right] \cdot \longrightarrow\left[\begin{array}{c}
\text { syllabic } \\
+ \text { low } \\
+ \text { tense }
\end{array}\right] \mathrm{C}
$$


The rule in (13) changes /w/, the second consonant in the nominal teplatic pattern CV.CVC, into /j/ when it occurs between two vowels, in which the preceding vowel is high short /i/ and the following vowel is low long /a:/ in CV.CVC.

\subsection{Vocalic substitution in $C A$}

Consider the list in (14) where a vowel is substituted for $/ \mathrm{w} /$ and $/ \mathrm{j} /$.

$\begin{array}{lll}\text { Input } & \text { Output } & \text { Gloss } \\ \text { /qawal/ } & \text { [qa:1] } & \text { 'said' } \\ \text { /baja// } & \text { [ba: } 9] & \text { 'sold' }\end{array}$

The glides $/ \mathrm{w} /$ and $/ \mathrm{j} /$ are vocalised when they occur between two vowels word-internally, as it is shown in (15), where null $\varnothing$ refers to the deletion of a segment (see appendix 2).

$$
\begin{aligned}
& \text { a. }\left[\begin{array}{c}
\text {-syllabic } \\
+ \text { sonorant } \\
\text { consonantal }
\end{array}\right] \longrightarrow\left[\begin{array}{c}
+ \text { syllabic } \\
+ \text { low } \\
+ \text { tense }
\end{array}\right] / \mathrm{C}\left[\begin{array}{c}
+ \text { syllabic } \\
+ \text { low } \\
- \text { tense }
\end{array}\right] \cdot \longrightarrow\left[\begin{array}{c}
+ \text { syllabic } \\
+ \text { low } \\
- \text { tense }
\end{array}\right] \mathrm{C} \\
& \mathrm{b}(1)\left[\begin{array}{c}
+ \text { syllabic } \\
+ \text { low } \\
\text { tense }
\end{array}\right] \longrightarrow \varnothing / \mathrm{C} \longrightarrow\left[\begin{array}{c}
+ \text { syllabic } \\
+ \text { low } \\
+ \text { tense }
\end{array}\right]\left[\begin{array}{c}
\text { +syllabic } \\
+ \text { low } \\
- \text { tense }
\end{array}\right] \mathrm{C} \\
& \mathrm{b}(2)\left[\begin{array}{c}
+ \text { syllabic } \\
+ \text { low } \\
- \text { tense }
\end{array}\right] \longrightarrow \varnothing / \mathrm{C}\left[\begin{array}{c}
+ \text { syllabic } \\
+ \text { low } \\
+ \text { tense }
\end{array}\right] \longrightarrow \mathrm{C}
\end{aligned}
$$

Three sequential phonological processes are required for the vocalisation of glides to occur in (15). The first process changes / $/ \mathrm{w} /$ or /j/, the second consonant in CV.CVC, into low long /a:/ when in between two low short /a/ in the templatic pattern for form I verb, CV.CVC. The second process deletes low short /a/ which is followed by low long /a:/ across a syllable. The third process deletes low short /a/ which is preceded by /a:/ word-internally. The two low short vowels have been deleted in (15 b) to avoid vowel adjacency. Consider the list in (16) where glides are vocalised word-finally.

$\begin{array}{lll}\text { Input } & \text { Output } & \text { Gloss } \\ \text { /danaw/ } & \text { [dana: } & \text { 'approached' } \\ \text { /ramaj/ } & \text { [rama: } & \text { 'threw' } \\ \text { /samaw/ } & \text { [sama:] } & \text { 'rose' } \\ \text { /Salaw/ } & \text { [Cala:] } & \text { 'rose' } \\ \text { /hawaj/ } & \text { [hawa: } & \text { 'fell off' } \\ \text { /talaw/ } & \text { [tala: } & \text { 'recited' }\end{array}$

The vocalisation that occurs in words such as [dana:] 'approached' and [rama:] 'threw' is represented phonologically in (17), where hash \# refers to a word boundary. 

a. $\left[\begin{array}{c}- \text { syllabic } \\ + \text { sonorant } \\ \text { - consonantal }\end{array}\right] \longrightarrow\left[\begin{array}{c}+ \text { syllabic } \\ + \text { low } \\ + \text { tense }\end{array}\right] / \mathrm{CV} \cdot \mathrm{C}\left[\begin{array}{c}\text { syllabic } \\ + \text { low } \\ - \text { tense }\end{array}\right] \longrightarrow \#$
b. $\left[\begin{array}{c}+ \text { syllabic } \\ + \text { low } \\ - \text { tense }\end{array}\right] \longrightarrow \emptyset / \mathrm{CV} \cdot \mathrm{C} \longrightarrow\left[\begin{array}{c}+ \text { syllabic } \\ + \text { low } \\ + \text { tense }\end{array}\right] \#$

The rule in (17a) changes glides $/ \mathrm{w} /$ and $/ \mathrm{j} /$ into low long $/ \mathrm{a} / \mathrm{w}$ wen they are preceded by low short $/ \mathrm{a} /$ in the templatic pattern for form I verb, CV.CVC word-finally. The rule in (17b) deletes low short /a/ which is followed by low long /a:/ to avoid occurrence of vowel adjacency. Now let us consider a different case where the glide $/ \mathrm{w} /$ is vocalised in the templatic pattern for tool noun, CVC.CVC in (18).

$$
\begin{array}{llll}
\text { Root } & \text { Input } & \text { Output } & \text { Gloss } \\
\text { wazan } & \text { /miwza:n/ } & \text { [mi:za:n] } & \text { 'scales' }
\end{array}
$$

The vocalisation that occurs in the output [mi:za:n] 'scales' is represented phonologically in (19).

(19) a. $\left[\begin{array}{c}\text {-syllabic } \\ + \text { sonorant } \\ + \text { round }\end{array}\right] \longrightarrow\left[\begin{array}{c}+ \text { syllabic } \\ + \text { high } \\ - \text { back } \\ + \text { tense }\end{array}\right] / \mathrm{C}\left[\begin{array}{c}\text { syllabic } \\ + \text { high } \\ - \text { back } \\ - \text { tense }\end{array}\right] \longrightarrow \cdot \mathrm{CVC}$

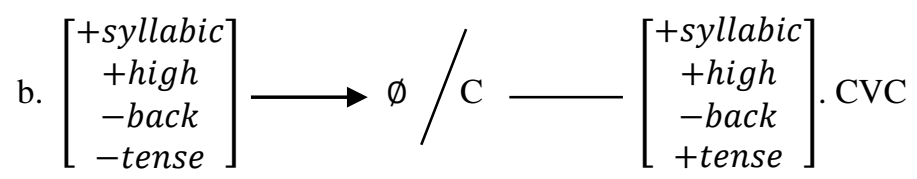

The glide /w/, the second consonant in the templatic pattern for tool noun, CVC.CVC, surfaces as high long /i:/ when it is preceded by high short /i/ word-internally in (19a). The rule in (19b) deletes high short /i/ which is followed by high long /i:/ word-internally to avoid occurrence of vowel adjacency. Now, consider vocalisation of the glide /j/ word-internally in (20).

$$
\begin{array}{cll}
\text { Input } & \text { Output } & \text { Gloss } \\
\text { /jujsir/ } & \text { [ju:sir }] & \text { 'facilitate' } \\
\text { /mujsir/ } & \text { [mu:sir }] & \text { 'active participle of facilitate' }
\end{array}
$$

The rule in (21) shows the phonological representation of the vocalisation of /j/.

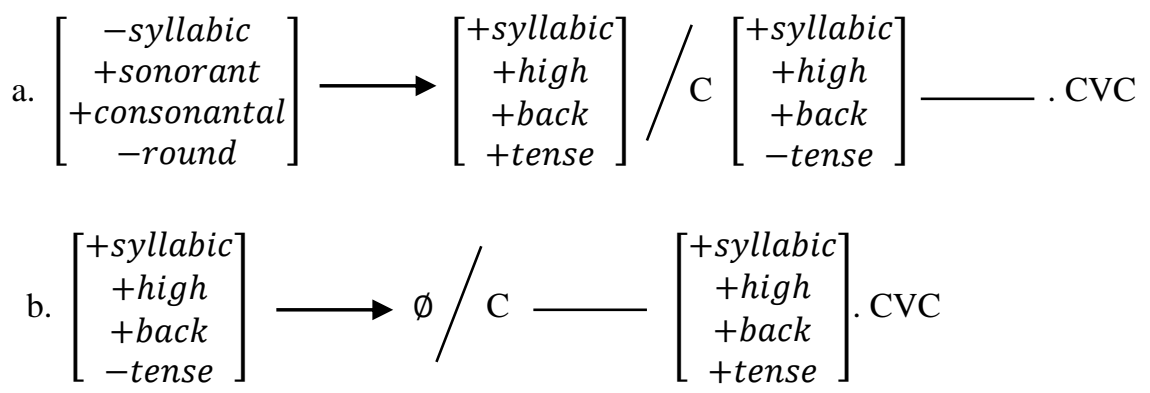


Two ordered phonological processes are required for the vocalisation of $/ \mathrm{j} /$ to occur in (21). The first process in (21a) changes / $\mathrm{j} /$ into high long back / $\mathrm{u}$ // when it is preceded by high short back / $\mathrm{u} /$ word-internally. The second process in (21b) deletes high short back/u/ which is followed by /u:/ word-internally to avoid occurrence of vowel adjacency.

\section{Conclusion}

This article aimed at investigating phonological substitution in CA. I hypothesised that consonantal and vocalic substitution is motivated by phonological features of adjacent consonantal or vocalic segments. It was referred to Aldiwan (2013) - an encyclopaedia of Arabic poetry, to collect data of the current study. Chomsky and Halle's (1968) SPE theory constituted a theoretical framework for the analysis of the data. Findings of the study have revealed that distinctive features of adjacent segments play a key role in motivating other adjacent consonants to undergo consonantal or vocalic substitution processes in CA.

It has been found that the round sonorant $/ \mathrm{w} /$, which occupies the second consonantal position in the templatic pattern for form VIII verb, CVC.CV.CVC, is replaced by /t/ when it is followed by the phoneme /t/ across a syllable in CVC.CV.CVC. In the case of tri-consonantal root morphemes which begin with /ș/, /ḍ/, /ț/, or /ọ/, the consonant /t/ which is the third consonant in the templatic pattern for form VIII verb CVC.CV.CVC becomes /t / when it is preceded by a consonant that has the features [+anterior, +coronal, +retracted tongue root]. The consonant $/ \mathrm{t} / \mathrm{can}$ also be replaced by $/ \mathrm{d} /$ in the same pattern when it is preceded by a consonant with either the features [-sonorant, -continuant, +voice, +anterior, -retracted tongue root] or [-sonorant, +continuant, +voice, +anterior, -retracted tongue root]. The consonant /w/, the second consonant in the nominal templatic pattern CV.CVC, becomes /j/ featuring [-syllabic, +sonorant, - consonantal, -round] when it occurs between two vowels, the first of which is high short /i/ and the second is low long /a:/, word-internally.

Findings have also revealed that the glides $/ \mathrm{w} /$ and $/ \mathrm{j} /$ which occupy the second consonantal position in CV.CVC become [+syllabic, +low, +tense] when in between two low short vowels in the templatic pattern for form I verb, CV.CVC. The two vowels, then, undergo deletion to avoid the occurrence of vowel adjacency. The glides $/ \mathrm{w} / \mathrm{and} / \mathrm{j} /$ also become [+syllabic, +low, +tense] when they are preceded by low short /a/ word-finally in the same templatic pattern. Then, the short vowel undergoes deletion to avoid vowel adjacency. The phoneme /w/, the second consonant in the templatic pattern for tool noun CVC.CVC, becomes [+syllabic, +high, -back, +tense] when it is preceded by high short vowel /i/ which then undergoes deletion, so that no vowel adjacency would occur. The glide /j/, the second consonant in CVC.CVC, becomes [+syllabic, +high, +back, +tense] when it is preceded by high short /u/ in the templatic pattern CVC.CVC, and the vowel/u/ undergoes deletion to avoid vowel adjacency.

\section{References}

Aldiwan, Encyclopaedia of Arabic poetry, (2013). Available at: https://www.aldiwan.net/

Chomsky, N., \& Halle, M. (1968). The Sound pattern of English. Cambridge, MA, MIT press.

Jakobson, R., Fant C. G. M., \& Halle, M. (1952). Preliminaries to speech analysis: The distinctive features and their correlates. Cambridge, MIT Press.

Rose, S. (1996). Variable laryngeals and vowel lowering. Phonology, 13, 73-117. https://doi.org/10.1017/S0952675700000191

Sa'aida, Z. (2020). Dominance in Coronal Nasal Place Assimilation: The Case of Classical Arabic. English Linguistics Research, 9(3), 25-35. https://doi.org/10.5430/elr.v9n3p25 


\section{Appendix 1}

List of classical Arabic consonantal and vocalic phonemes (Sa'aida: 2020, 35)

1. $/ \mathrm{t} /$ : voiceless plain dental plosive.

2. /ț/: voiceless emphatic dental plosive.

3. $/ \mathrm{k} /$ : voiceless velar plosive.

4. /q/: voiceless uvular plosive.

5. /R/: voiceless glottal plosive.

6. $/ \mathrm{b} /$ : voiced bilabial plosive.

7. /d/: voiced plain dental plosive.

8. / $/ \mathrm{d} /$ : voiced emphatic dental plosive.

9. /f/: voiceless labiodental fricative.

10. $/ \theta /$ : voiceless inter-dental fricative.

11. /ð/: voiced inter-dental fricative.

12. $/ \mathrm{s} /$ : voiceless plain alveolar fricative.

13. /ș/: voiceless emphatic alveolar fricative.

14. / $/$ /: voiceless post-alveolar fricative.

15. $/ \chi /$ : voiceless uvular fricative.

16. $/ \mathrm{h} /$ : voiceless pharyngeal fricative.

17. $/ \mathrm{h} /$ : voiceless glottal fricative.

18. /z/: voiced plain alveolar fricative.

19. /ọ/: voiced emphatic alveolar fricative.

20. /dz/: voiced post-alveolar fricative.

21. /в/: voiced uvular fricative.

22. $/ \varsigma /$ : voiced pharyngeal varies between fricative and approximant.

23. /m/: bilabial nasal.

24. /n/: alveolar nasal.

25. /1/: alveolar lateral.

26. /r/: alveolar trill.

27. /w/: labial-velar glide.

28. /j/: palatal glide.

29. /i/: high front short vowel.

30. /u/: high back rounded short vowel.

31. /a/: low short vowel.

32. /i:/: high front long vowel.

33. /u:/: high back rounded long vowel.

34. /a:/: low long vowel. 


\section{Appendix 2}

\section{List of abbreviations and symbols}

1. CA refers to classical Arabic.

2. C refers to a consonant.

3. V refers to a vowel.

4. Hash \# refers to a word boundary, either initially or finally.

5. Null $\varnothing$ refers to the deletion of a segment.

6. Dot. refers to a syllable boundary.

\section{Copyrights}

Copyright for this article is retained by the author(s), with first publication rights granted to the journal.

This is an open-access article distributed under the terms and conditions of the Creative Commons Attribution license (http://creativecommons.org/licenses/by/4.0/). 